\title{
Investigation of Toxin-Producing and Antibiotic-Resistant Bacillus cereus in Spices Used in the Production of Sucuk
}

\author{
Ece Çetin ${ }^{1}$, Görkem Yaman $^{2}$, Artun Yıbar ${ }^{3 *}$ \\ 1* Tekirdag Namik Kemal University, Faculty of Veterinary Medicine, Departmant of Food Hygiene and Technology, Tekirdag, Turkey, (ORCID: 0000-0002-8783- \\ 5507), ecetin@nku.edu.tr \\ 2 Düzen Laboratories Group, Mecidiyeköy Branch, Department of Microbiology and Tuberculosis, İstanbul, Turkey, (ORCID: 0000-0001-5278-0174), \\ gyaman@hotmail.com \\ ${ }^{3}$ Bursa Uludag University, Faculty of Veterinary Medicine, Department of Food Hygiene and Technology, Bursa, Turkey, (ORCID: 0000-0001-9510-5734), \\ artunyibar@uludag.edu.tr
}

(First received 17 October 2021 and in final form 6 December 2021)

(DOI: 10.31590/ejosat.1010007)

ATIF/REFERENCE: Cetin, E., Yaman, G. \& Yıbar, A. (2021). Investigation of Toxin-Producing and Antibiotic-Resistant Bacillus cereus in Spices Used in the Production of Sucuk. European Journal of Science and Technology, (31), 331-340.

\begin{abstract}
In this study, a total of 100 samples of seven types of spices were investigated to determine the presence of toxin-producing and multiple antibiotic-resistant Bacillus cereus and other food-borne microorganisms. The spices tested included 18 samples of ground black pepper (Piper nigrum), 17 samples of red pepper (Capsicum frutescens), 12 samples of ground red pepper (Capsicum frutescens), 20 samples of cummin (Cuminum cyminum), 16 samples of pimento (Pimenta dioica), nine samples of garlic powder (Allium sativum) and eight samples of sucuk spice mixes that were obtained from various retail shops and sucuk production units in the Bursa province between January and December 2014. These spices are used to prepare sucuk because of their flavouring and seasoning properties. The samples were analysed for Bacillus cereus, Escherichia coli, coagulase-positive Staphylococcus aureus, Salmonella spp., yeast, moulds and coliforms. For the identification of B. cereus, Matrix-Assisted Laser Desorption/Ionization Timeof-Flight Mass Spectrometry (MALDI-TOF-MS, Germany) was used. The analysis showed that all samples had coliform, yeast and mould and $B$. cereus maximum and minimum counts between $<10$ and $1.1 \times 10^{5} \mathrm{cfu} / \mathrm{g}, 1 \times 10^{2}$ and $9.3 \times 10^{4} \mathrm{cfu} / \mathrm{g}$, and $1 \times 10^{2}$ and $4.8 \times 10^{4}$ $\mathrm{cfu} / \mathrm{g}$, respectively. Furthermore, coagulase-positive $S$. aureus was identified in five samples, E. coli was identified in two samples, and Salmonella spp. was identified in none. A total of $39(92.8 \%)$ B. cereus isolates were resistant to two or more antibiotic agents. In addition, $31(73.8 \%)$ B. cereus isolates tested positive for production of both non-haemolytic enterotoxin (NHE) and haemolysin BL (HBL) enterotoxins. These results show that some spices contain harmful microorganisms. To reduce microbial counts and to improve poor microbiological quality in spices, hygiene programmes must be corrected in the pre- and post-harvesting period.
\end{abstract}

Keywords: Spices, Sucuk, Bacillus cereus, Multiple antibiotic resistance, Toxin producing, MALDI-TOF.

\section{Sucuk Üretiminde Kullanılan Baharatlarda Toksin Üreten ve Antibiyotiğe Dirençli Bacillus cereus'un Araştırılması}

\section{$\ddot{O} \mathbf{z}$}

Bu çalışmada, toksin üreten ve çoklu antibiyotiklere dirençli Bacillus cereus ve diğer gıda kaynaklı mikroorganizmaların varlığını belirlemek için yedi çeşit baharattan toplam 100 numune araştırılmıştır. Çalışmanın amacı doğrultusunda; Ocak ve Aralık 2014 tarihleri arasında Bursa ilinde, çeşitli perakende satış mağazaları ve sucuk üretim ünitelerinden elde edilen 18 kara biber örneği (Piper nigrum), 17 kırmızı pul biber örneği (Capsicum frutescens), 12 toz kırmızı biber örneği (Capsicum frutescens), 20 kimyon numunesi (Cuminum cyminum), 16 yenibahar örneği (Pimenta dioica), dokuz sarımsak tozu (Allium sativum) ve sekiz sucuk baharatı karışımları örnekleri analiz edilmiştir. Bu baharatlar, aromaları ve baharat özelliklerinden dolayı sucuk hazırlamak için kullanılmaktadır. Örnekler, Bacillus cereus, Escherichia coli, koagülaz pozitif Staphylococcus aureus, Salmonella spp., Maya-küf ve koliformlar yönünden analiz edilmiştir. Bacillus cereus'un tanımlanmasında Matrix-Assisted Laser Desorption/Ionization Time-ofFlight Mass Spectrometry (MALDI-TOF-MS, Germany) kullanıldı. Analizler, tüm örneklerin koliform, maya ve küf ve B. cereus en yüksek ve en düşük sayılarının sırasıyla $<10$ and $1.1 \times 10^{5} \mathrm{cfu} / \mathrm{g}, 1 \times 10^{2}$ and $9.3 \times 10^{4} \mathrm{cfu} / \mathrm{g}$, and $1 \times 10^{2}$ and $4.8 \times 10^{4} \mathrm{cfu} / \mathrm{g}$ arasında olduğunu gösterdi. Ayrıca, beş örnekte koagülaz pozitif $S$. aureus, iki örnekte E. coli belirlenirken, hiçbir örnekte Salmonella spp.

* Corresponding Author: artunyibar@uludag.edu.tr 
varlığı tespit edilemedi. Toplam 39 (\% 92.8) B. cereus izolatının iki veya daha fazla antibiyotik ajana dirençli olduğu belirlendi. Ek olarak, B. cereus izolatlarının 31 (\% 73.8) adeti non-hemolitik enterotoksin (NHE) ve hemolizin BL (HBL) enterotoksinlerinin üretimi için pozitif test edildi. Bu sonuçlar, bazı baharatların zararlı mikroorganizmaları içerdiğini göstermektedir. Mikrobiyal sayımı azaltmak ve baharatlarda zayıf mikrobiyolojik kaliteyi arttırmak için hijyen programları hasat öncesi ve hasat sonrası düzeltilmelidir.

Anahtar Kelimeler: Baharat, Sucuk, Bacillus cereus, Çoklu antibiyotik direnci, Toksin üretimi, MALDI-TOF.

\section{Introduction}

Sucuk is a popular traditional meat product that is produced from minced beef meat, hard beef fat tissue, salt, nitrite and/or nitrate and various spices including cumin, garlic, black pepper, pimento, and red pepper (Pehlivanoglu et al., 2015). However, sucuk may contain microorganisms that first come in contact with the meat through exposure to air and water, through employee handling, or through the spices used in its production. These microorganisms can seriously affect the health of anyone who consume these products.

Spices are valuable products that grow in a natural environment and are commonly used in a variety of ways, including in the preparation of meat products. Spices are a key ingredient throughout the world because of the preservation, flavouring, colouring and aromatic properties they confer to meat products, particularly sucuk, salami, pastrami and meatballs (Hampikyan et al., 2009; Verluyten et al., 2004). However, the use of contaminated spices in meat products can add to the existing microflora and thus impair the quality of these products and cause serious foodborne illness (KoohyKamaly-Dehkordy et al., 2013; Shinagawa et al., 1988). Yeasts and moulds, coliforms, Escherichia coli, Salmonella spp., Staphylococcus aureus, and the toxin-producing and sporeforming bacterium Bacillus cereus are the known possible contaminants of spices.

The spore-forming, toxin-producing bacterium B. cereus is one of the possible contaminants of spices (Eglezos, 2010). This bacterium can be found in soil and is widely distributed in the environment. B. cereus causes severe food poisoning, producing a diarrhoeal syndrome induced by haemolysin BL (HBL) and non-haemolytic enterotoxin (NHE) (Hansen and Hendriksen, 2001; Lund and Granum, 1996). B. cereus spores are heatresistant and can germinate when cooled improperly, and the nutrients within meat support the growth of the resulting vegetative cells (Eglezos, 2010). Spices may also contain the enterotoxigenic $B$. cereus, usually at counts below $10^{3} \mathrm{cfu} / \mathrm{g}$ but sometimes at higher levels $\left(10^{5}-10^{6} \mathrm{cfu} / \mathrm{g}\right)$, and food to which it is added may cause food poisoning if the product is inappropriately handled or stored (Cameron, 1998; Little et al., 2003). In the study conducted by Aksu et al. (2000), 63.44\% of the spices were found to be contaminated with $B$. cereus ranging between $10^{2}$ and $3.2 \times 10^{3} \mathrm{cfu} / \mathrm{g}$. A survey performed by Tulu et al. (2013) showed coliform counts ranging from $3.8 \times 10^{5}$ to 1.0 X $10^{6} \mathrm{cfu} / \mathrm{g}$ in red chilli spice samples.

Although B. cereus has been isolated from various spices at rates ranging from 28\% to $100 \%$ (Hampikyan et al., 2009; Aksu et al., 2000; Erol et al., 1999; Agaoglu et al., 1999) there have not been any studies that have investigated the enterotoxinproducing capabilities or the antibiotic resistance of B. cereus in spices in Turkey.

Yeast and moulds may also contaminate spices. Mould contamination is dangerous due to their production of mycotoxins. These microorganisms have previously been isolated from various spices (Moss and Baker, 2000; Banerjee and Sarkar, 2003). Spices may be contaminated by coliforms associated with improper and inadequate hygienic practices and faecal contamination, E. coli in particular. The presence of $E$. coli in red pepper spice samples was reported by Parveen et al. (2014). Salmonella spp. is a leading cause of acute bacterial gastroenteritis, and S. aureus is another important foodborne pathogen. Several studies have reported the contamination of spices by both microorganisms. For instance, Banarjee and Sarker (2003) reported Salmonella spp. in $2.6 \%$ of spice samples. In the U.S., Julseth and Deibel (1974) found S. aureus in two of 12 black pepper samples.

In 2011, the Republic of Turkey Ministry of Food, Agriculture and Livestock established a maximum limit of $10^{4}$ cfu/g spice of both coagulase-positive $S$. aureus and B. cereus. Salmonella spp. count should be zero in a $25 \mathrm{~g}$ sample.

The purpose of this study was to establish the microbiological quality of spices used in sucuk production in the Bursa province in relation to the presence of toxin-producing and antibiotic-resistant $B$. cereus. In addition, yeast and moulds, coliforms, E. coli, coagulase-positive S. aureus and Salmonella spp. were investigated. To our knowledge, this is the first report on the incidence of toxigenic and multiple antibiotic-resistant $B$. cereus in spices in Turkey.

\section{Material and Method}

\subsection{Sample Collection}

Between January and December 2014, a total of 100 samples of seven types of spices, including 18 samples of ground black pepper, 17 samples of red pepper, 12 samples of ground red pepper, 20 samples of cumin, 16 samples of pimento, nine samples of garlic powder and eight samples of sucuk spice mixes, were purchased from various markets, retail shops and sucuk production premises located in the Bursa province of Turkey. The samples were transported to the laboratory and analysed as soon as possible at $<4^{\circ} \mathrm{C}$.

\subsection{Isolation and Identification of Salmonella spp.}

Salmonella spp. isolation was performed according to the ISO 6579 standard (ISO, 2002). Briefly, the sample preenrichment was combined with $225 \mathrm{ml}$ Buffered Peptone Water (Merck, Belgium), homogenized for two min with a Seward Stomacher 80 Lab System (Seward, London, UK) and incubated at $37^{\circ} \mathrm{C}$ for $24 \mathrm{~h}$. After pre-enrichment and incubation, $1 \mathrm{ml}$ of the sample was transferred to Muller-Kauffmann TetrathionateNovobiocin Broth (Oxoid, UK), and $0.1 \mathrm{ml}$ of the sample was transferred to Rappaport-Vassiliadis Medium with Soya Broth (Oxoid, UK). The inoculated broths were incubated for primary enrichment for $24 \mathrm{~h}$ at $37^{\circ} \mathrm{C}$ and $41.5^{\circ} \mathrm{C}$. After incubation, the cultures were inoculated using a loop onto both Xylose Lysine Deoxycholate (Merck, Belgium) agar and Xylose Lysine Tergitol (Merck; Belgium) agar. After selective plating at $37^{\circ} \mathrm{C}$ for $24 \mathrm{~h}$, potential Salmonella colonies were subjected to biochemical identification by API 20E (bioMerieux, France). 


\subsection{Isolation and Identification of Coliforms and E. coli}

For coliform and E. coli isolation and enumeration, serial 10 -fold dilutions of samples were made in saline peptone water and plated onto the relevant selective media. Total coliform was grown on Violet Red Bile (Bio life, Italy) agar using the "pour" plate technique, and plates with 30-300 colonies were used for enumeration after $24-48$ hours of incubation at $37^{\circ} \mathrm{C}$. After the incubation, typical colonies (red colonies with halos) were inoculated into lactose broth (Oxoid, UK) in a Durham tube for $44^{\circ} \mathrm{C} 24 \mathrm{~h}$. After incubation, acid and gas formation-positive colonies were confirmed to be E. coli using the IMVC series of tests (indole, methyl red, Voges-Proskauer and citrate). Indol (+), methyl red (+), Voges-Proskauer (-) and citrate (-) indicated the presence of $E$. coli type- 1 .

\subsection{Isolation and Identification of Coagulase- positive $S$. aureus}

All samples were serially diluted in $9 \mathrm{ml}$ of saline peptone water, and each dilution was spread on Baird Parker Agar (Oxoid, UK) plates. The plates were incubated at $37^{\circ} \mathrm{C}$ for $48 \mathrm{~h}$. All colonies on Baird Parker with opaque halos surrounded by a clear zone were accepted as coagulase-positive $S$. aureus. From each Baird Parker Agar plate, 2 typical colonies were chosen, and a coagulase test was conducted for confirmation.

\subsection{Isolation and Identification of Yeast and Moulds}

Saline peptone water was used as a diluent for samples, and each dilution was spread on Potato Dextrose Agar (Oxoid, UK) using the spread plate method. Plates were incubated at $22^{\circ} \mathrm{C}$ for 3-5 days.

\subsection{Isolation of $B$. cereus}

All samples were serially diluted in $9 \mathrm{ml}$ of saline peptone water, and each dilution was spread on Bacara Agar (bioMerieux, France) using the spread-plate method. Plates were incubated at $30^{\circ} \mathrm{C}$ for $48 \mathrm{~h}$. Following incubation, plates were examined for typical colonies (pink/orange with halos), and at least one colony of each typical colony type was picked from each of the plates for identification using Matrix-assisted laser desorption/ionization time-of-flight mass spectrometry (MALDI-TOF-MS, Germany).

\subsection{Identification of Presumptive $B$. cereus Colonies Using MALDI-TOF-MS}

Identification of the isolates was performed using MALDITOF MS by the Duzen Laboratories Group in Istanbul. For this purpose, the colonies of presumptive B. cereus were subcultured to Tryptic Soy Agar (Oxoid, UK) and were confirmed using MALDI-TOF-MS. This technique is a promising platform for quick, flexible, and reliable identification of isolates originating from food. A portion or the whole colony on Tryptic Soy Agar (Oxoid, UK) agar was directly transferred onto a spot on the 96spotted polished steel target plate. The spot was then covered with $1 \mu \mathrm{l}$ of CHCA matrix solution. After air drying completely, the plate was loaded into the Bruker Microflex LT (Bruker Daltonics, Germany) instrument. The spectra were generated in linear positive ion mode with delayed extraction in a mass range of 4 to $10 \mathrm{kDa}$ using a $337 \mathrm{~nm}$ nitrogen laser with a frequency of $60 \mathrm{~Hz}$. The automated data analysis was processed with MALDI Biotyper Realtime Classification and Biotyper software version 3.1 (Bruker Daltonics). The obtained spectra were analysed using a standard pattern-matching algorithm, which compared the raw spectra with the spectra of the Bruker library using the standard settings. The results were listed in a ranking table, expressed as log (score) values ranging from 0 to 3 as recommended by the manufacturer. Score values of $>1.7$ generally indicate relationships at the genus level, and values of $>2.0$ generally indicate relationships at the species level. The highest score was used for species identification. The Bruker library contains $>80,000$ spectra covering 2048 species and 385 genera. If the result was below 1.7, the colony was transferred into screw cap tubes and mixed thoroughly in $0.3 \mathrm{ml}$ of doubledistilled ultrapure water. Next, $0.9 \mathrm{ml}$ of pure ethanol was added to the tubes, and after vortexing, they were centrifuged at 13,000 $\times \mathrm{g}$ for $2 \mathrm{~min}$. The supernatant was discarded, and the pellet was mixed thoroughly with $50 \mu \mathrm{l}$ of $70 \%$ aqueous formic acid. After the addition of $50 \mu \mathrm{l}$ of acetonitrile, the mixture was centrifuged at $13,000 \times \mathrm{g}$ for $2 \mathrm{~min}$. One microliter of the microorganism extract supernatant was placed onto the polished steel and covered with $1 \mu \mathrm{l}$ of CHCA matrix solution and loaded to the instrument. Data analysis was processed as previously described.

\subsection{Screening of Enterotoxic B. cereus}

Haemolytic enterotoxin (HBL) and non-haemolytic enterotoxin (NHE) production were assessed using the Duopath ${ }^{\circledR}$ Cereus Enterotoxins Test kit (Merck, Belgium) according to the manufacturer's instructions. Briefly, B. cereus isolates were suspended in $1 \mathrm{ml}$ Caseinhydrolysate Glucose Yeast extract Broth (Base) (Merck, Belgium) (with 1\% glucose) and incubated at $37^{\circ} \mathrm{C}$ for $4 \mathrm{~h}$. The Caseinhydrolysate Glucose Yeast extract Broth (Base) (Merck, Belgium) preparations were cooled to room temperature; then, $150 \mu \mathrm{l}$ was transferred to the circular sample port on the test. The results were read after 30 minutes.

\subsection{Antibiotic Resistance Testing}

Antibiotic resistance of $B$. cereus isolates was tested using Mueller-Hinton Agar (Oxoid, UK) by the Kirby-Bauer disc diffusion method (Bauer et al., 1966). The disks used (Oxoid) and antibiotic concentrations were as follows: ampicillin (AMP, $10 \mu \mathrm{g})$, penicillin $\mathrm{G}(10 \mathrm{U})$, tetracycline $(30 \mu \mathrm{g})$, erythromycin $(15 \mu \mathrm{g})$, kanamycin $(30 \mu \mathrm{g})$, chloramphenicol $(30 \mu \mathrm{g})$, neomycin (30 $\mu \mathrm{g})$, oleandomycin $(15 \mu \mathrm{g})$, cephalothin $(30 \mu \mathrm{g})$, streptomycin $(10 \mu \mathrm{g})$, polymyxin $\mathrm{B}(300 \mathrm{U})$, and vancomycin $(30 \mu \mathrm{g})$. B. cereus ATCC 10876 was used as control strain. According to the inhibition zone measured, the isolates were classified as resistant or susceptible as recommended by Bauer et al. (1966).

\section{Results and Discussion}

In total, 100 samples consisting of seven types of spices, including 18 samples of ground black pepper, 17 samples of red pepper, 12 samples of ground red pepper, 20 samples of cumin, 16 samples of pimento, nine samples of garlic powder and eight samples of sucuk spice mixes were analysed to determine their microbiological quality. The results obtained in this study are summarized in Table 1 . The results of testing for the identification and toxin-producing capability of $B$. cereus isolates are shown in Table 2. The number of resistant and susceptible B. cereus isolates are indicated in Table 3. In addition, multiple antibiotic resistance patterns observed among B. cereus isolates are given in Table 4 .

This analysis revealed that the samples had coliform, yeast and mould, and B. cereus counts between $<10$ and $1.1 \times 10^{5} \mathrm{cfu} / \mathrm{g}$, $1 \times 10^{2}$ and $4.4 \times 10^{5} \mathrm{cfu} / \mathrm{g}$ and $1 \times 10^{2}$ and $4.8 \times 10^{4} \mathrm{cfu} / \mathrm{g}$, respectively. The average coliform counts of ground black pepper, red pepper, pimento, cumin, ground red pepper, garlic 
powder and sucuk spice mixes were $2.7 \times 10^{3} \mathrm{cfu} / \mathrm{g}(61.11 \%)$, $9 \times 10^{1} \mathrm{cfu} / \mathrm{g}(5.88 \%), 4.2 \times 10^{3} \mathrm{cfu} / \mathrm{g}(50 \%), 1.7 \times 10^{4} \mathrm{cfu} / \mathrm{g}(55 \%)$, $2.3 \times 10^{4} \mathrm{cfu} / \mathrm{g}(33.33 \%), 3.7 \times 10^{2} \mathrm{cfu} / \mathrm{g}(22.22 \%)$ and $2.3 \times 10^{4}$ $\mathrm{cfu} / \mathrm{g}(100 \%)$, respectively. E. coli was identified in two sucuk spice mixes ( $25 \%$ of those tested). Coagulase-positive $S$. aureus was isolated in five samples (5\% of those tested), and Salmonella spp. were found in none of them.

In the present study, yeast and mould were counted in samples of ground black pepper, red pepper, pimento, cumin, ground red pepper, garlic powder and sucuk spice mixes at the average levels of $7.5 \times 10^{4} \mathrm{cfu} / \mathrm{g}(33.33 \%), 3.4 \times 10^{3} \mathrm{cfu} / \mathrm{g}$ (29.41\%), $1.3 \times 10^{4} \mathrm{cfu} / \mathrm{g}(56.25 \%), 2.5 \times 10^{3} \mathrm{cfu} / \mathrm{g}(35 \%), 4.0 \times 10^{4}$ $\mathrm{cfu} / \mathrm{g}(66.66 \%), 9.5 \times 10^{2} \mathrm{cfu} / \mathrm{g}(22.22 \%), 1.3 \times 10^{4} \mathrm{cfu} / \mathrm{g}(62.5 \%)$, respectively. Additionally, the highest contamination levels of yeast and moulds $\left(4.4 \times 10^{5} \mathrm{cfu} / \mathrm{g}\right)$ were obtained from ground black pepper.

In the current study, $100 \%(\mathrm{n}=42)$ of $B$. cereus isolates produced NHE enterotoxin. Further, 31 (73.8\%) of the B. cereus isolates tested positive for both NHE and HBL enterotoxins.

The resistance of $B$. cereus isolates against penicillin $\mathrm{G}$ was found to be $92.8 \% \quad(n=39)$, followed by ampicillin $(83.3 \%$; $\mathrm{n}=35)$, cephalotin $(80.9 \% ; \mathrm{n}=34)$ and polimixin $\mathrm{B}(61.9 \%$; $\mathrm{n}=26)$. Resistance to tetracycline (14.2\%), kanamycin $(11.9 \%)$, oleondamycin $(2.3 \%)$, erythromycin $(2.3 \%)$ and vancomycin $(2.3 \%)$ were also observed in our study. No isolates were resistant to chloramphenicol, streptomycin or neomycin (Table 3).

In 2011, the Republic of Turkey Ministry of Food, Agriculture and Livestock established a maximum limit of $10^{4}$ $\mathrm{cfu} / \mathrm{g}$ spice of both coagulase-positive $S$. aureus and B. cereus. Salmonella spp. count should be zero in a $25 \mathrm{~g}$ sample. Varying counts of coliform bacteria have been reported in different spices. Elmali and Yaman (2005) indicated that coliform microorganism counts were $1.1 \times 10^{4}, 1.3 \times 10^{4}, 4.2 \times 10^{2}, 4.5 \times 10^{3}$ and $1.0 \times 10^{3} \mathrm{cfu} / \mathrm{g}$ for black pepper, powdered red pepper, granulated red pepper, cumin and sumac, respectively. In another work (Vural, 2004), the average coliform counts of ground black pepper, red pepper, pimento, cumin and ground red pepper were $5.9 \times 10^{3}, \quad 1.6 \times 10^{4}, \quad 1.9 \times 10^{4}, 2.5 \times 10^{4}$ and $9.9 \times 10^{4} \mathrm{cfu} / \mathrm{g}$, respectively.

These results are in accordance with the values found in the current study. On the other hand, the average coliform count of red pepper in this study $\left(9 \times 10^{1} \mathrm{cfu} / \mathrm{g}\right)$ was closer to those reported by other groups. A survey performed by Parveen et al. (2014) showed a coliform count of $7.20 \times 10^{1} \mathrm{MPN} / \mathrm{g}$ in red pepper. In the present study, we didn't find any contamination with E.coli in the samples. However, a survey performed by Vural (2004) indicated that the average counts of $E$. coli were $4.8 \times 10^{3}, 1.6 \times 10^{4}, 4.2 \times 10^{2}, 5.4 \times 10^{2}$ and $6.5 \times 10^{2} \mathrm{cfu} / \mathrm{g}$ in ground black pepper, red pepper, pimento, cumin and ground red pepper, respectively. E. coli was found in $26.6 \%$ of the samples investigated by Elmali and Yaman (2005). In another work (Debs-Louka et al., 2013), E. coli counts ranged from $<10$ to $9 \times 10^{3} \mathrm{cfu} / \mathrm{g},<10$ to $3 \times 10^{4} \mathrm{cfu} / \mathrm{g}$ and $<10$ to $7 \times 10^{3} \mathrm{cfu} / \mathrm{g}$ in black pepper powder, seven spices mixture and cumin powder, respectively.

Elmali and Yaman (2005) reported yeast and mould counts in black pepper, powdered red pepper, granulated red pepper and cumin samples at the average numbers of $3.8 \times 10^{5}, 1.2 \times 10^{5}$, $3.4 \times 10^{6}, 4.2 \times 10^{4}$ and $1 \times 10^{6} \mathrm{cfu} / \mathrm{g}$, respectively. These results are close to the bacterial counts obtained in our study. On the other hand, Parveen et al. (2014) counted yeast and mould at the average number of $1 \times 10^{2} \mathrm{cfu} / \mathrm{g}$ in red pepper alone. Filiz (2001) reported the presence of yeast and mould at the average number of $5 \times 10^{2} \mathrm{cfu} / \mathrm{g}$. Vural (2004) reported $4 \times 10^{3}, 1.3 \times 10^{4}, 1.9 \times 10^{3}$ and $1.5 \times 10^{4} \mathrm{cfu} / \mathrm{g}$ of yeast and mould in ground black pepper, red pepper, pimento, cumin and ground red pepper, respectively, which is in agreement with the results of this study.

In the current study, Salmonella spp. was found in none of the spice samples. Similarly, Debs-Louka et al. (2013) and García et al. (2001) found no Salmonella spp. in a variety of spice samples. On the other hand, in the study of Sagoo et al. (2009), 2833 dried spices and herbs of different varieties were sampled across the United Kingdom in 2009, and thirty-one $(1.1 \%)$ herb samples were found to have been contaminated with different Salmonella serovars at retail premises.

Konuma et al. (1988) reported that B. cereus was present in $39.7 \%$ of tested spices at levels between $10^{2}-10^{4} \mathrm{cfu} / \mathrm{g}$. Similar results were reported by Deambrosis and Da Silva (1992), who found that the rate of isolation of $B$. cereus from spice samples was $41 \%$. Our results are consistent with these observations. On the other hand, Kneifel and Berger (1994) and Rosenberger and Weber (1993) reported the absence of B. cereus in spices.

In our study, the highest contamination levels (unsatisfactory) $\left(\geq 10^{4} \mathrm{cfu} / \mathrm{g}\right)$ were obtained from cumin $\left(4.8 \times 10^{4}\right.$ and $\left.1 \times 10^{4} \mathrm{cfu} / \mathrm{g}\right)$, ground black pepper $\left(4.6 \times 10^{4}, 1.1 \times 10^{4}\right.$ and $\left.1 \times 10^{4} \mathrm{cfu} / \mathrm{g}\right)$ and pimento $\left(1.9 \times 10^{4} \mathrm{cfu} / \mathrm{g}\right)$ for $B$. cereus. A similar result has been observed by Aksu et al. (2000) who found the maximum B. cereus count was in cumin. Moreover, $8 \%(8$ out of 100) of spices tested did not comply with (unsatisfactory or unacceptable quality) both the Turkish Food Codex criteria (2011) and the Commission Recommendation 2004/24/EC for B. cereus counts $\left(\right.$ B. cereus $\left.\geq 10^{4} \mathrm{cfu} / \mathrm{g}\right)$. These findings are similar to data reported by several researchers (Powers et al., 1976; De Boer et al., 1985; Pafumi, 1986; Kovács-Domján, 1988; Giaccone et al., 1996; Te Giffel et al., 1997). In comparison to our results, higher $(5.72 \log 10 \mathrm{cfu} / \mathrm{g})$ and lower B. cereus levels (3.93 $\log 10 \mathrm{cfu} / \mathrm{g}$ ) were observed by Hampikyan et al. (2009) and Elmali and Yaman (2005), respectively. In another previous study, B. cereus was detected at levels $\geq 10^{4} \mathrm{cfu} / \mathrm{g}$ in $0.3 \%$ (2/647) of single spice samples (3rd Trimester National Microbiological Survey, 2005).

In a few extreme cases $B$. cereus at levels reaching $10^{5}-10^{8}$ $\mathrm{cfu} / \mathrm{g}$ have been reported in various spices (Banerjee and Sarkar; 2003; Antai, 1988). However, most reports indicate the presence of this pathogen at levels which are in agreement with our findings $\left(<3 \times 10^{3} \mathrm{cfu} / \mathrm{g}\right)$. In other studies of the microbiological status of herbs and spices, B. cereus was detected at $\geq 10^{4} \mathrm{cfu} / \mathrm{g}$ in up to $49 \%$ of tested samples (Hampikyan et al., 2009; Little et al., 2003; Sagoo et al., 2009; Kneifel and Berger, 1994; Pafumi, 1986; Temelli and Anar, 2002).

In previous studies, Hariram and Labbe (2015) identified the production of both enterotoxins in $52 \%$ of $\mathrm{B}$. cereus isolates from spice samples. The high prevalence of the NHE enterotoxin among $B$. cereus isolates has been demonstrated in many studies (Hariram et al., 2015; Guinebretiere et al., 2002; Moravek et al., 2006; Schoen1 et al., 2005; Wehrle et al., 2009; Yang et al., 2005). We also obtained positive results for NHE in $100 \%$ $(n=34)$ of our samples. Hariram and Labbe (2015) identified HBL enterotoxin production in $87 \%$ of $B$. cereus isolates. 
European Journal of Science and Technology

Table 1. Presence of yeast \& mold, coagulase positive S. aureus, coliforms \& E. coli in spice samples $(n=100)$

\begin{tabular}{|c|c|c|c|c|c|c|c|c|}
\hline \multirow{3}{*}{ Sample type (st) } & \multicolumn{8}{|c|}{ Microorganism } \\
\hline & \multicolumn{2}{|c|}{ Yeast \& mold } & \multicolumn{2}{|c|}{ Coagulase positive $S$. aureus } & \multicolumn{4}{|c|}{ Coliform \& E. coli } \\
\hline & $\begin{array}{l}\text { No positive / } \\
\text { no st }(\%)\end{array}$ & Mean (cfu/g) & $\begin{array}{l}\text { No positive / } \\
\text { no st }(\%)\end{array}$ & $\begin{array}{c}\text { Mean } \\
\text { (cfu/g) }\end{array}$ & $\begin{array}{c}\text { Coliform positive / } \\
\text { no st }(\%)\end{array}$ & Mean (cfu/g) & $\begin{array}{c}\text { E. coli positive / } \\
\text { Coliform positive (\%) }\end{array}$ & Mean $(\mathrm{cfu} / \mathrm{g})$ \\
\hline Red pepper & $5 / 17(29)$ & $3.4 \times 10^{3}$ & $2 / 17(12)$ & $1.6 \times 10^{3}$ & $1 / 17(6)$ & $9 \times 10^{1}$ & $1 / 1(100)$ & $9 \times 10^{1}$ \\
\hline Ground red pepper & $8 / 12(67)$ & $4.0 \times 10^{4}$ & $0 / 12(0)$ & - & $4 / 12(33)$ & $2.3 \times 10^{4}$ & $0 / 4(0)$ & - \\
\hline Ground black pepper & $6 / 18(33)$ & $7.5 \times 10^{4}$ & $1 / 18(6)$ & - & $11 / 18(61)$ & $2.7 \times 10^{3}$ & $0 / 11(0)$ & - \\
\hline Pimento & $9 / 16(56)$ & $1.3 \times 10^{4}$ & $1 / 16(6)$ & - & $8 / 16(50)$ & $4.2 \times 10^{3}$ & $0 / 8(0)$ & - \\
\hline Cummin & $7 / 20(35)$ & $2.5 \times 10^{3}$ & $0 / 20(0)$ & - & $11 / 20(55)$ & $1.7 \times 10^{4}$ & $0 / 11(0)$ & - \\
\hline Garlic powder & $2 / 9(22)$ & $9.5 \times 10^{2}$ & $0 / 9(0)$ & - & $2 / 9(22)$ & $3.7 \times 10^{2}$ & $0 / 2(0)$ & - \\
\hline Sucuk spice mix & $5 / 8(63)$ & $1.3 \times 10^{4}$ & $1 / 8(13)$ & - & $8 / 8(100)$ & $2.3 \times 10^{4}$ & $2 / 8(25)$ & $2.7 \times 10^{3}$ \\
\hline Total & $42 / 100$ & & $5 / 100$ & & $45 / 100$ & & $3 / 100$ & \\
\hline
\end{tabular}


Table 2. The results of testing for isolation, identification and toxin-producing capability of B. cereus isolated from spices $(n=49)$

\begin{tabular}{|c|c|c|c|c|c|}
\hline \multirow[t]{3}{*}{ Sample } & \multirow{3}{*}{$\begin{array}{l}\text { Isolation } \\
\text { B. cereus count } \\
\text { (cfu/g) }\end{array}$} & \multicolumn{2}{|c|}{ Identification } & \multicolumn{2}{|c|}{ Toxin production } \\
\hline & & \multicolumn{2}{|c|}{ MALDI-TOF-MS } & \multirow[t]{2}{*}{ NHE } & \multirow[t]{2}{*}{ HBL } \\
\hline & & Positive & Log (score) & & \\
\hline Red pepper (1) & $2 \times 10^{2}$ & + & 2.053 & + & + \\
\hline Red pepper (15) & $4 \times 10^{2}$ & + & 2.082 & + & + \\
\hline Red pepper (75) & $1 \times 10^{2}$ & + & 2.014 & + & + \\
\hline Red pepper (82) & $2 \times 10^{2}$ & + & 1.958 & + & - \\
\hline Ground red pepper (6) & $1 \times 10^{3}$ & + & 1.780 & + & + \\
\hline Ground red pepper (11) & $1.2 \times 10^{2}$ & - & - & - & - \\
\hline Ground red pepper (49) & $2 \times 10^{3}$ & + & 2.087 & + & + \\
\hline Ground red pepper (59) & $1 \times 10^{3}$ & + & 2.234 & + & + \\
\hline Ground black pepper (13) & $4.6 \times 10^{4}$ & + & 1.860 & + & + \\
\hline Ground black pepper (34) & $1 \times 10^{4}$ & + & 2.114 & + & + \\
\hline Ground black pepper (40) & $9.8 \times 10^{3}$ & + & 2.024 & + & - \\
\hline Ground black pepper (47) & $1 \times 10^{3}$ & + & 1.998 & + & - \\
\hline Ground black pepper (57) & $2.2 \times 10^{3}$ & + & 2.098 & + & + \\
\hline Ground black pepper (61) & $2 \times 10^{2}$ & + & 2.136 & + & + \\
\hline Ground black pepper (62) & $2 \times 10^{3}$ & + & 2.227 & + & + \\
\hline Ground black pepper (71) & $1 \times 10^{2}$ & + & 2.153 & + & + \\
\hline Ground black pepper (79) & $1 \times 10^{3}$ & + & 2.02 & + & + \\
\hline Ground black pepper (83) & $5 \times 10^{2}$ & + & 2.138 & + & - \\
\hline Ground black pepper (84) & $1.1 \times 10^{4}$ & + & 1.782 & + & + \\
\hline Cummin (4) & $4.8 \times 10^{4}$ & + & 1.948 & + & + \\
\hline Cummin (9) & $1.1 \times 10^{3}$ & + & 1.764 & + & + \\
\hline Cummin (16) & $1 \times 10^{4}$ & + & 2.233 & + & - \\
\hline Cummin (46) & $2 \times 10^{2}$ & + & 1.981 & + & + \\
\hline Cummin (72) & $1 \times 10^{2}$ & - & - & - & - \\
\hline Cummin (76) & $2 \times 10^{2}$ & + & 1.898 & + & + \\
\hline Garlic powder (10) & $2 \times 10^{4}$ & + & 1.838 & + & - \\
\hline Garlic powder (17) & $3 \times 10^{3}$ & + & 1.953 & + & - \\
\hline Garlic powder (51) & $1 \times 10^{3}$ & - & - & - & - \\
\hline Garlic powder (55) & $3 \times 10^{2}$ & + & 2.228 & + & + \\
\hline Garlic powder (70) & $1.5 \times 10^{4}$ & - & - & - & - \\
\hline Garlic powder (95) & $4 \times 10^{2}$ & + & 1.551 & + & + \\
\hline Sucuk spice mixes (19) & $7 \times 10^{2}$ & + & 1.864 & + & + \\
\hline Sucuk spice mixes (45) & $1 \times 10^{2}$ & - & - & - & - \\
\hline Sucuk spice mixes (74) & $7 \times 10^{3}$ & + & 1.848 & + & + \\
\hline Sucuk spice mixes (89) & $2 \times 10^{2}$ & + & 2.237 & + & + \\
\hline Sucuk spice mixes (100) & $1 \times 10^{2}$ & + & 1.976 & + & + \\
\hline
\end{tabular}

NHE: nonhaemolytic enterotoxin, HBL: haemolysin BL, + positive, - negative 
Table 3. Number of resistant and susceptible B. cereus isolates to 12 different antibiotics

\begin{tabular}{lll}
\hline \multirow{2}{*}{ Antibiotics } & \multicolumn{2}{c}{ No. of $\mathbf{B}$. cereus isolates $(\mathbf{n}=\mathbf{4 2})$} \\
\cline { 2 - 3 } & $\begin{array}{l}\text { No. of resistant } \\
\text { isolates }\end{array}$ & $\begin{array}{l}\text { No. of susceptible } \\
\text { isolates }\end{array}$ \\
\hline Oleondamycin $(15 \mu \mathrm{g})$ & 1 & 39 \\
Tetracycline $(30 \mu \mathrm{g})$ & 6 & 26 \\
Polymixin B $(300 \mathrm{U})$ & 26 & - \\
Chloramphenicol $(30 \mu \mathrm{g})$ & - & 38 \\
Erythromycin $(15 \mu \mathrm{g})$ & 1 & 37 \\
Penicillin $\mathrm{G}(10 \mathrm{U})$ & 39 & - \\
Cephalothin $(30 \mu \mathrm{g})$ & 34 & 7 \\
Ampicillin $(10 \mu \mathrm{g})$ & 35 & 7 \\
Kanamycin $(30 \mu \mathrm{g})$ & 5 & 26 \\
Vancomycin $(30 \mu \mathrm{g})$ & 1 & 40 \\
Streptomycin $(10 \mu \mathrm{g})$ & - & 42 \\
Neomycin $(30 \mu \mathrm{g})$ & - & 42 \\
\hline
\end{tabular}

Table 4. Multidrug resistance patterns observed among B.cereus isolates $(n=39)$

\begin{tabular}{|c|c|c|}
\hline Source & $\begin{array}{l}\text { No. of multiple } \\
\text { resistant isolates }\end{array}$ & $\begin{array}{l}\text { Resistance } \\
\text { pattern }\end{array}$ \\
\hline Red pepper & 1 & \multirow[b]{2}{*}{$\mathrm{P}, \mathrm{PB}$} \\
\hline Ground red pepper & 1 & \\
\hline Garlic powder & 1 & $\mathrm{P}, \mathrm{AMP}$ \\
\hline Cummin & 1 & $\mathrm{P}, \mathrm{PB}, \mathrm{AMP}$ \\
\hline Sucuk spice mixes & 2 & \multirow{5}{*}{ P, KF, AMP } \\
\hline Pimento & 2 & \\
\hline Ground black pepper & 2 & \\
\hline Garlic powder & 1 & \\
\hline Cummin & 3 & \\
\hline Garlic powder & 1 & \multirow[b]{2}{*}{$\mathrm{P}, \mathrm{PB}, \mathrm{KF}$} \\
\hline Cummin & 1 & \\
\hline Ground red pepper & 1 & \multirow{5}{*}{$\mathrm{P}, \mathrm{PB}, \mathrm{KF}, \mathrm{AMP}$} \\
\hline Pimento & 3 & \\
\hline Red pepper & 3 & \\
\hline Ground black pepper & 5 & \\
\hline Sucuk spice mixes & 1 & \\
\hline Ground red pepper & 1 & \multirow{2}{*}{$\mathrm{P}, \mathrm{KF}, \mathrm{AMP}, \mathrm{TE}$} \\
\hline Garlic powder & 1 & \\
\hline Cummin & 1 & \multirow[b]{2}{*}{ P, PB, KF, AMP, TE } \\
\hline Ground black pepper & 1 & \\
\hline Ground black pepper & 4 & $\mathrm{P}, \mathrm{PB}, \mathrm{KF}, \mathrm{AMP}, \mathrm{K}$ \\
\hline Ground black pepper & 1 & $\mathrm{P}, \mathrm{PB}, \mathrm{KF}, \mathrm{AMP}, \mathrm{TE}, \mathrm{K}$ \\
\hline Pimento & 1 & P, KF, AMP, VA, E, OL \\
\hline
\end{tabular}

$\overline{\mathrm{Ol}}$, oleandomycin; Te, tetracycline; $\mathrm{Pb}$, polymixin $\mathrm{B}$; $\mathrm{C}$, chloramphenicol; $\mathrm{E}$, erythromycin; $\mathrm{P}$, penicillin $\mathrm{G}$;

Kf, cephalothin; Amp, ampicillin; K, kanamycin; Va, vancomycin; S, streptomycin; N, neomycin 
The broad application of antimicrobials in agriculture and veterinary medicine may lead to the emergence of resistant pathogens. These pathogens may enter the food chain through various foods, including meat and meat products, and may potentially affect human health (Khachatourians, 1998; Phillips et al., 2004). A remarkable variation to a wide range of antimicrobial agents has been described in the resistance of B. cereus isolated from spices in studies worldwide. Multiple antibiotic-resistant B. cereus has been reported to be associated with some food samples (Tewari et al., 2012; Meena et al., 2000).

A total of $41(97.6 \%)$ B. cereus isolates were resistant to at least one antibiotic agent (Table 3) and 39 (92.8\%) were resistant to two or more antibiotic agents (Table 4). This is in agreement with previous data that found high resistance rates in bacterial populations from spices (Hassan and Altalhi, 2013; Brown and Jiang, 2008). In only one isolate from red pepper (3\% of total isolates from this source), no resistance was found (data not shown). In addition, 11 different patterns of multiple resistance were detected among the $\mathrm{B}$. cereus isolates ranging from resistance to 2 drugs to resistance to 6 drugs. The most common multiple antibiotic resistance pattern was penicillin $G$, polymyxin B, cephalothin and ampicillin, which was observed in $33.3 \%(n=13)$ of isolates.

Previous work has shown that B. cereus isolates are highly susceptible to chloramphenicol and tetracycline and less sensitive to penicillin (Whong and Kwaga, 2007). In respect to chloramphenicol, penicillin and tetracycline resistance, our results align with those of Whong and Kwaga (2007), who determined chloramphenicol, penicillin and tetracycline resistance percentages of $0 \%, 82 \%$ and $6.7 \%$, respectively, for B. cereus isolates from various foods, including spice samples.

\section{Conclusions and Recommendations}

To the authors' best knowledge, this is the first report on the incidence of toxigenic and multidrug resistant B. cereus in spices in Turkey.

As shown in this study, a significant subset of the spices studied contained high numbers of B. cereus. Further, multidrug resistance and toxin production were observed in a majority of the isolates. The multidrug resistance patterns observed in this study suggest that these antibiotic agents are highly abused and can be found at sublethal doses in the environment. Occurrence of multidrug resistance and diarrhoeal toxin-producing B. cereus in high proportions of spices used in meat products may pose a significant public health hazard (Tewari, 2012).

Manufacturers should understand the microbiological risks involved in production of meat products and should apply a farm-to-table approach to food safety. Manufacturers may also use sterilized spices to reduce the risk of contamination of meat products with these microorganisms. As a recommendation, we can say that manufacturers should source spices from certified suppliers complying with systems such as QA, GMP and ISO systems. They should also apply GMP rules, and HACCP systems should be applied in their premises.

\section{Acknowledge}

This manuscript was edited before submission by American Journal Experts (AJE).

\section{References}

Agaoglu, S., Sancak, Y. C., Alisarli, M., Ekici, K. 1999. The presence of B. cereus in some spice varieties offered for sale in Van market. Journal of Research in Veterinary Medicine, 1-2(18), 89-96.

Aksu, H., Bostan, K., Ergün, Ö. 2000. Presence of Bacillus cereus in packaged some spices and herbs sold in Istanbul. Pakistan Journal of Biological Sciences, 3(5), 710-712.

Antai, S. P., 1988. Study of Bacillus flora of Nigerian spices. International Journal of Food Microbiology, 6: 259-261.

Banerjee, M., Sarkar, P. K. 2003. Microbiological quality of some retail spices in India. Food Research International, 36: 469-474.

Bauer, A. W., Kirby, W. M., Sherris, J. C., Truck, M. 1966. Antibiotic susceptibility testing by a standardized single disk method. American Journal of Clinical Pathology, 45: 493496.

Brown, J. C., Jiang, X. 2008. Prevalence of antibiotic-resistant bacteria in herbal products. Journal of Food Protection, 71(7), 1486-90.

Cameron, G. 1998. Need to consider Bacillus subtilis as a cause of food poisoning. New Zealand Public Health Surveillance Report, 5(2), 11.

Deambrosis, N., Da Silva, A. 1992. Incidence of Bacillus cereus in spices. Proceedings of the 3rd World Congress on Feodborne Infections and Intoxications, 1: 316, Berlin.

De Boer, E., Spielenberg, W. M., Janssen, F. W. 1985. Microbiology of spice and herbs. Antonie Van Leeuwenhoek International Journal of General and Molecular Micr, 51: 435-438.

Debs-Louka, E., Zouki, J. E., Dabboussi, F. 2013. Assessment of the microbiological quality and safety of common spices and herbs Sold in Lebanon, Journal of Food and Nutritional Disorders, 2: 4.

Eglezos, S., Huang, B., Dykes, E. A., Fegan, N. 2010. The prevalence and concentration of Bacillus cereus in retail food products in Brisbane, Australia. Foodborne Pathogens and Disease, 7 (7), 1-3.

Elmal1, M., Yaman, H. 2005. Microbiological Quality of some spices sold in the Markets of Bitlis District. Erciyes University Journal of the Faculty of Veterinary Medicine, 2(1), 9-14.

Erol, İ., Küplülü, Ö., Karagöz, S. 1999. Microbiological quality of some spices consumed in Ankara. Veterinary Journal of Ankara University, 46: 115-125.

Filiz, N. 2001. Microbial flora of some ground spices consumed in Bursa, Journal of Research in Veterinary Medicine, 20: 103-107.

García, S., Iracheta, F., Galván, F., Heredia, N. 2001. Microbiological survey of retail herbs and spices from Mexican markets. Journal of Food Protection, 64: 99-103.

Giaccone, V., Colavita, G., Torriani, S., Ciocca, R. M., Augelli, R. 1996. Occurrence of Bacillus cereus and other Bacillus spp. in spices. Archiv Für Lebensmittelhygiene, 47(2), 47 49.

Guinebretiere, M. H., Broussolle, V., Nguyen-The, C. 2002. Enterotoxigenic profiles of food-poisoning and food-borne Bacillus cereus strains. Journal of Clinical Microbiology, 40: 3053-3056.

Hampikyan, H., Bingol, E. B., Colak, H., Aydin, A. 2009. The evaluation of microbiological profile of some spices used in 
Turkish meat industry. Journal of Food, Agriculture and Environment, 7(3-4), 111-115.

Hansen, B. M., Hendriksen, N. B.2001. Detection of enterotoxic Bacillus cereus and Bacillus thuringiensis strains by PCR analysis. Applied and Environmental Microbiology Journal, 67(1), 185-189. https://doi.org/10.1128/AEM.67.1.185189.2001.

Hariram, U., Labbé, R.2015. Spore prevalence and toxigenicity of Bacillus cereus and Bacillus thuringiensis isolates from U.S. retail spices. Journal of Food Protection, 78(3), 590596.

Hassan, S. A., Altalhi, A. D. 2013. Safety assessment of spices and herbs consumed in Saudi Arabia: Microbiological Quality and Toxin Production. Life Science Journal, 10(4), 2819-2827.

International Organization for Standardization (ISO 6579: 2002). 2002. Microbiolgy of food and animal feeding stuffsHorizontal method for detection of Salmonella spp. Geneva, Switerland.

Julseth, R. M., Deibel, R. H. 1974. Microbial profile of selected spices and herbs at Import. Journal of Milk and Food Technology, 37: 414-419.

Khachatourians, G. G. 1998. Agricultural use of antibiotics and the evolution and transfer of antibiotic-resistant bacteria. Canadian Medical Association Journal, 159(9), 1129-1136.

Kneifel, W., Berger, E. 1994. Microbiological criteria of random samples of spices and herbs retailed on the Austrian Market. Journal of Food Protection, 57: 839-901.

Konuma, H., Shinagawa, K., Tokumaru, M., Onoue, Y., Konno, S., Fujino, N., Shigehisa, T., Kurata, H., Kuwabara, Y., Lopes, C. A. M. 1988. Occurrence of Bacillus cereus in meat products, raw meat and meat product additives. Journal of Food Protection, 51(4), 324-326.

Koohy-Kamaly-Dehkordy, P., Nikoopour, H., Siavoshi, F., Koushki, M., Abadi, A. 2013. Microbiological quality of retail spices in Tehran, Iran. Journal of Food Protection, 76(5), 843-852. https://doi.org/10.4315/0362-028X.JFP-12180

Kramer, J. M., Gilbert, R. J. 1989. Bacillus cereus and other Bacillus species. In, Doyle MP (Ed): Foodborne Bacterial Pathogens. 21-70, Marcel Dekker, New York.

Kovács-Domján, H. 1988. Microbioligical investigation of paprika and pepper with special regard to sporeformers including B. cereus. Acta Alimentaria, 17: 257-264.

Little, C. L., Omotoye, R., Mitchell, R. T. 2003. The microbiological examination of ready-to-eat foods to which spices have been added. International Journal of Environmental Health Research, 13(1), 31-42.

Lund, T., Granum, P. E. 1996. Characterisation of a nonhaemolytic enterotoxin complex from Bacillus cereus isolated after a foodborne outbreak. FEMS Microbiology Letters, 141(2-3), 151-6.

Meena, B. S., Kapoor, K. N., Agarwal, R. K. 2000. Occurrence of multi-drug resistant Bacillus cereus in foods. Journal of Food Science and Technology, 37: 289-291.

Moravek, M., Dietrich, R., Buerk, C., Broussolle, V., Guinebretière, M. H., Granum, P. E., Nguyen-The, C., Märtlbauer, E. 2006. Determination of the toxic potential of Bacillus cereus isolates by quantitative enterotoxin analyses. FEMS Microbiology Letters, 257(2), 293-8.

Moss, M. O., Baker, T. 2000. Teaching Techniques for Mycology: 10. Moulds from spices; Eurotium species. Mycologist, 14(2), 54-57.
Pafumi, J. 1986. Assessment of the microbiological quality of spices and herbs. Journal of Food Protection, 49(12), 958963.

Parveen, S., Das, S., Begum, A., Sultana, N., Hoque, M. M., Ahmad, I. 2014. Microbiological quality assessment of three selected spices in Bangladesh. International Food Research Journal, 21(4), 1327-1330.

Pehlivanoglu, H., Nazli, B., Imamoglu, H., Cakır, B. 2015. Piyasada fermente sucuk olarak satılan ürünlerin kalite özelliklerinin saptanması ve geleneksel türk fermente sucuğu ile karşılaştırılması. J Fac Vet Med Istanbul Univ, 41(2), 191-198.

Phillips, I., Casewell, M., Cox, T., Brad De Groot, Friis, C., Jones, R., Nightingale, C., Preston, R., Waddell, J. 2004. Does the use of antibiotics in food animals pose a risk to human health? A critical review of published data. Journal of Antimicrobial Chemotherapy, 53: 28-52. https://doi.org/10.1093/jac/dkg483

Rosenberger, A., Weber, H. 1993. Keimbelastung von gewurzproben. Mikrobiologischer status im hinblick auf richt und warnwerte. Fleischwirtsch, 73: 830-833.

Powers, E. M., Latt, T. G., Brown, T. 1976. Incidence and levels of Bacillus cereus in processed spices. Journal of Milk and Food Technology, 39(10), 668-670.

Sagoo, S. K., Little, C. L., Greenwood, M., Mithani, V., Grant, K. A., McLauchlin, J., Pinna, E., Threlfall, E. J. 2009. Assessment of the microbiological safety of dried spices and herbs from production and retail premises in the United Kingdom. Food Microbiology, 26: 39-43.

Schoen1, J. L., Wong, A. C. L. 2005. Bacillus cereus food poisoning and its toxins. Journal of Food Protection, 68(3), 636-648.

Shinagawa, H., Makino, K., Amemura, M., Kimura, S., Iwasaki, H., Nakata, A. 1988. Structure and regulation of the Escherichia coli ruv operon involved in DNA repair and recombination. Journal of Bacteriology, 170: 4322-4329.

Te Giffel, M. C., Beumer, R. P., Granum pe, Rombouts, F. M.1997. Isolation and characterisation of Bacillus cereus from pasteurised milk in household refrigerators in the Netherlands. International Journal of Food Microbiology, 34, 307-318.

Temelli, S., Anar, S. 2002. Prevalence of Bacillus cereus in spices and herbs marketed in Bursa. Journal of Faculty of Veterinary Medicine, Istanbul University, 28(2), 459-465.

Tewari, A., Singh, S. P., Singh, R. 2012. Prevalence of multidrug resistant Bacillus cereus in foods and human stool samples in and around Pantnagar, Uttrakhand. Journal of Advanced Veterinary and Animal Research, 2: 252-255.

Turkısh Food Codex Microbiological Criteria Regulation, 2011.

Third Trimester National Microbiological Survey, 2005. EU Coordinated programme. Bacteriological Safety of Prepackaged Mixed Salads.

Tulu S, Demissie S, Dabassa A: Mikrobial safety of some selected spices sold in Jimma Town, South Western of Ethiopia. Res J Microbiol, 9(1): 43-50, 2013.

Verluyten, J., Leroy, F., Luc de Vuyst. 2004. Effects of different spices used in production of fermented sausages on growth of and curvacin a production by Lactobacillus curvatus LTH 1174. Applied and Environmental Microbiology Journal, 70(8), 4807-4813. https://doi.org/10.1128/AEM.70.8.48074813.2004 
Vural, A. 2004. Investigation on the microbiological quality of consumed some spices in Diyarbakır province. Kafkas Universitesi Veteriner Fakultesi Dergisi, 10(1), 13-18.

Wehrle, E., Moravek, M., Dietrich, R., Bürk, C., Didier, A., Märtlbauer, E. 2009. Comparison of multiplex PCR, enzyme immunoassay and cell culture methods for the detection of enterotoxinogenic Bacillus cereus. Journal of Microbiological Methods, 78: 265-270.

Whong, C. M. Z., Kwaga, J. K. P. 2007. Antibiograms of Bacillus cereus isolates from some Nigerian foods. Nigerian Food Journal, 25(1), 178-183.

Yang, I. C., Shih, D. Y., Huang, T. P. 2005. Establishment of a novel multiplex PCR assay and detection of toxigenic strains of the species in the Bacillus cereus group. Journal of Food Protection, 68: 2123-30. https://doi.org/10.4315/0362-028X68.10 .2123 